\title{
Kendala Orangtua dalam Mendidik Anak Usia Dini pada Saat Pandemi Covid 19
}

\author{
Eva Mufaziah $^{1 凶}$, Puji Yanti Fauziah ${ }^{2}$ \\ Pendidikan Luar Sekolah, Universitas Negeri Yogyakarta \\ DOI: $\underline{10.31004 / o b s e s i . v 5 i 2.746}$
}

\begin{abstract}
Abstrak
Tujuan dari peneltian adalah mengetahui kendala orangtua dalam mendidik AUD pada saat pandemic covid-19. Pendekatan penelitian menggunakan kuantitatif dengan metode servey. Populasi nya adalah orangtua yang memiliki AUD Usia 3-7 tahun. Pengumpulan data menggunakan angket di sebar secara online melalui whatapps dengan bantuan google form. Instrument penelitian merupakan turunan dari teori. Sampel yang digunakan 54 orangtua dari Provinsi DIY, Jawa Tengah dan Jawa Barat. Hasil Penelitian adalah kendala orangtua di pengaruhi faktor eksternal dan internal dalam mendidik anak. Faktor internal kendala yang dihadapi orangtua adalah kecapakan dalam hal mendidik anak dan kendala faktor eksternal yang dihadapi oleh orangtua adalah media pembelajaran. Maka perlu solusi dalam memberikan kecapakan kepada orangtua baik dari pemerintah maupun sekolah serta penggunaan media yang ada disekitar orangtua dan AUD agar dapat melakukan pendidikan secara efektif tanpa kendala pada masa pandemic Covid-19 yang mampu menjawab tantangan di era globalisasi.
\end{abstract}

Kata Kunci: kendala orangtua; faktor internal dan eksternal mendidik aud; pandemi covid-19

\begin{abstract}
The purpose of this research is to see the close distance of parents in educating AUD during the Covid-19 pandemic. The research approach uses a quantitative survey method. The population is the elderly who have AUD ages 3-7 years. Data collection using questionnaires is distributed online via WhatsApp with the help of a google form. The research instrument is a derivative of the theory. The sample used was 54 parents from Yogyakarta, Central Java and West Java Provinces. The result of this research is that parents' problems are influenced by external and internal factors in educating children. Internal faktors related to parents are skill in educating children and external factors related to parents are learning media. So the solution that needs to give happiness to parents from both the government and schools as well as the use of media around parents and AUD so that they can carry out education effectively without supervision during the Covid-19 pandemic that is able to answer the challenges in the era of globalization
\end{abstract}

Keywords: parental constraints; internal and external faktors educating aud; the covid-19 pandemic

Copyright (c) 2020 Eva Mufaziah, Pujiyanti Fauziah

$\triangle$ Corresponding author:

Email Address : evamufaziah.2018@student.uny.ac.id (Yogyakarta, Indonesia)

Received 4 September 2020, Accepted 28 September 2020, Published 29 September 2020 


\section{PENDAHULUAN}

Indonesia saat ini sedang mengalami wabah covid-19. Wabah covid-19 ini tidak hanya terjadi di Indonesia saja, namun terjadi di dunia atau secara global (Syafrida \& Hartati, 2020:495). Tentunya wabah ini memberikan dampak kepada masyarakat. Tidak hanya di bidang ekonomi atau pariwisata ternyata di pendidikan pun wabah covid-19 ini memberikan dampat langsung karena yang biasa pembelajaran dilakukan di dalam kelas, ternyata pada saat ini pendidikan dilakukan di rumah atau di luar sekolah. Padahal seharusnya ketika pendidikan di canangkan di rumah saja tentunya perlu persiapan yang matang baik dari guru, siswa ataupun orangtua yang sekerang menjadi pendamping dalam belajar anak. Pengantisi pasian di Indonesia sudah tersebar diseluruh daerah salah satu kebijakannya dengan melakukan seluruh aktivitas di rumah saja (Yunus \& Rezki, 2020: 228).

Pembelajaran formal di sekolah terdampak juga karena adanya wabah covid-19. Akhirnya sekolah di lakukan di rumah. Tentunya tugas guru sebagian di ambil alih oleh orangtua yang pada kondisi seperti ini tidak semua orangtua dapat memahami bagaimana cara mendidik pada saat pandemi covid-19. Pada saat ini sekolah yang awalnya focus pada keterampilan akademik tradisional pada saat pandemi ini pembelajaran dilakukan secara online (Salkiah, 2020:3781). Padahal pada kenyataan pembelajaran online sejalan dengan kemajuannya bidang teknologi atau digital sehingga ini merupakan tantangan bagi seluruh pihak di bidang pendidikan baik pemerintah, sekolah ataupun orangtua harus dapat mengikuti kemajuan saat ini (Darmalaksana et al., 2020).

Undang-undang Nomor 20 tahun 2003 menjelaskan tentang Sistem Pendidikan Nasional pasal 1, butir 14 yang menjelaskan bahwa PAUD adalah suatu upaya pembinaan yang ditujukan bagi anak sejak ia lahir sampai dengan usia enam tahun, yang dilakukan melalui pemberian rangsangan pendidikan untuk membantu pertumbuhan dan perkembangan jasmani dan rohani agar anak memiliki kesiapan dalam memasuki pendidikan lebih lanjut (dalam Andriani, 2012:121). Aktivitas sekolah didalam rumah dilakukan dari malai PAUD sampai dengan tingkat universitas. Pada saat pembelajaran dilakukan di rumah tentunya setiap orangtua perlu kesiapan dalam mendidik anak-anaknya. maka orangtua menjadi seorang pendidik juga, pendidik pada orangtua yakni seperti menjadi falisilitator. Sedang fasilitator memiliki peran tersendiri dalam mendidik anak yakni dapat memberikan suasana belajar yang menyenangakan, gembira, penuh semangat, tidak cemas, dan berani salam mengemukakan pendapat (Arifin \& Fardana, 2014:190). Pada saat pandemi berlangsung juga banyak orangtua yang mengeluh mengenai semangat anak yang mulai turun dan bosan ketika belajar di rumah (Sari et al., 2020:472). Ketika pendidikan dilakukan baik di dalam sekolah ataupun di rumah tentunya pasti selalu memiliki kendala. Menurut helmawati (Helmawati, 2014) menjelaskan bahwa kendala-kendala dalam pendidikan berasal dari dua faktor, yaitu faktor internal dan eksternal. Faktor internal dalam mendidik tentunya dapat dilihat dari diri anaknya sendiri sendangkan faktor eksternalnya dapat dilihat dari luar diri anak tersebut.Kendala dalam mendidikan anak terutama pada anak usia dini dapat dilihat dari faktor internalnya melalui: 1) Faktor genetic yang merupakan turunan dari orangtua nya atau dari gen yang di wariskan orangtua kepada anaknya. 2) Faktor fisik yang terganggu akan dapat mengganggu atau memengaruhi proses pendidikan alat. 3) Faktor Psikologis juga akan mengganggu proses pendidikan anak baik sifat malas, manja, takut dn lainnya akan merugikan atau menghambat orangtua dalam mendidik anaknya.

Kendala selanjutnya yang dapat di hadapi orangtua dapat dilihat dari faktor eksternal, yaitu: 1) Faktor Pendidik dalam proses pendidikan memiliki peran yang sangat penting baik dalam memberikan baik dari rasa perhatiannya maupun dari keterampilan seorang pendidik dalam mengajar akan mempengaruhi pembelajaran 2) Faktor Keluarga yang harmonis akan berpengaruh pada proses mendidik anak 3) Faktor ekonomi. 4) Faktor social 5) Faktor Budaya dan 6) faktor keamanan dan kenyamanan. Selain itu, sebagian besar orangtua di Indonesia masih belum menyadari betapa pentingnya pendidikan anak usia dini bagi setiap individu anak serta bagi masa depan bangsa kita (Suryani, 2007:42). Apalagi saat ini tingkatan 
pencapaian perkembangan anak usia dini seperti yang telah ditetapkan tidak mudah untuk dapat di capai dengan maksimal sesuai dengan standar pencapaian perkembangan anak usia ini pada saat pandemi covid-19 ini (Putra, 2020:80).

Terdapat dua kendala yang dihadapi orangtua yaitu; internal dan eksternal. Kendala internal berupa karakteristik, minat, kecakapan, pengalaman-pengalaman, sikap, motivasi, konsentrasi, kecerdasan, kesiapan fisik maupun mental (Helmawati, 2014: 234-241). Sedangkan kendala eksternal dilihat dari pendidik, lingkungan (waktu dan tempat), teman sebaya, masyarakat, kurikulum, media, pembiayaan serta sarana dan prasana.

Kendala internal dalam mendidik anak yang pertama adalah karakteristik. Karakteristik ini ada dapat menjadi kendala bagi orangtua apabila ketika sedang belajar tidak bisa mengatur emosial atau malas dalam mendidik anak usia dini. Kedua minat, dimana minat ini merupakan keinginan anak dalam hal melakukan sesuatu. Ketiga kecakapan(pengetahuan), dalam hal ini pendidik atau peserta harus memahami terlebih dahulu mengenai cara mendidik anak, terutama pada saat ini masa pandemi. Keempat pengelaman-pengalaman orangtua yang dapat berpengaruh terhadap cari mendidik anak dini. Kelima sikap, sikap ini bisa berupa sikap keras atau tegas dalam mendidik anaknya. keenam adalah motivasi, dimana motivasi ini sangat berpengaruh agar anak memiliki dorongan agar terus belajar, ketujuh konsentrasi yang sangat penting dalam mendidik anak sangat berpengaruh terhadap mendidik anak. Kedelapan kecerdasan orangtua dalam mendidikan akan menghasilkan hasil belajar yang baik. Kesiapan fisik dan mental orangtua dalam mengajar pula dapat berpengaruh terhadap proses pembelajaran yang dilakukan.

Kendala eksternal dalam mendidik adalah pertama, pendidik atau orangtua. Guru yang mengintruksikan secara langsung kegiatan belajar mengajar baik dari pemberian tugas dan lainnya. Kedua lingkungan, lingkungan dapat dilihat baik tempat belajar dan waktu belajar dapat menghambat proses pembelajaran. Ketiga adalah teman baik, teman baik pada proses pembelajarann akan saling melengkapi dan memberi makna pembelajaran yang dilakukan. Keempat masyarakat, dimana masyarakata menjadi salah satu faktor yang dapat mempengaru pada pendidikan. Kelima kurikulum, tentunya kurikulum berpengaruh terhadap proses pembelajaran anak karena menjadi acuan dalam proses pembelajaran. Keenam media, media dan alat yang di gunakan sesuai dengan perkembangan jalan yang terus berjalan tentunya menurut sebagian ornag ini menjadi kendala. Ketujuh biaya, banyak sekali ekonomi pada saat ini yang mulai menurun sehingga pembiayaan pendidikan terdampak karena ekonomi orangtua menurun. Yang terakhir adlah sarana dan prasana, yang tentunya sarana dan prasarana menjadi perhatiaan yang cukup serius karena merupakan penunjang atau alat menyampaikan tujuan pendidikan (Helmawati, 2014).

Berdasarkan paparan tersebut peneliti tertarik untuk melakukan penelitian mengenai kendala-kendala yang dihadapi orangtua dalam mendidik anak usia dini pada saat pendemi saat pembelajaran dilakukan di rumah dengan tujuan dapat memberikan pemahaman bagi orangtua di rumah dalam mendidik anak usia dini pada masa pandemi. Sehingga peneliti mengharapkan bahwa kendala-kendala yang di hadapi oleh orangtua dapat semakin berkurang dan adanya solusi agar orangtua dapat mengantisipasi kendala-kendala yang dihadapi sehingga pendidikan dilakukan sesuai dengan keadaan saat masa pandemi namun tetap pada ranah pendidikan yang sesuai.

\section{METODOLOGI}

Pendekatan yang di gunakan dalam penelitian ini adalah kualitatif dengan metode survey. Survey digunakan untuk mengetahui kendala yang dihadapi oleh orangtua ketika mendidik anak dimasa pandemi. Dalam hal ini kendala yang dimaksud adalah kendala orangtua yang memiliki anak usia dini saat melakukan pembelajaran dirumah pada saat masa pandemi. Data penelitian didapat secara online dengan menggunakan google form yang disebar melalui whatapps. Responden dalam penelitian berjumlah 53 orangtua yang mamiliki anak usia dini kirasan usia 3-7 tahun yang berada pada wilayah Jawa Barat, Daerah Istimewa 
Yogyakarta dan Jawa Tengah. Instrumen dalam penelitian ini berupa angket. Pengolahan data yang digunakan pada penelitian ini secara langsung di olah oleh system docs.google.com. Sistem tersebut secara langsung dapat menghasilkan persentase dari data berdasarkan pernyataan-pernyataan yang dijawab oleh responden. Berikut merupakan tahapan dalam penelitian:

\begin{tabular}{c}
$\begin{array}{c}\text { Analisis } \\
\text { Kebutuhan } \\
\text { Lapangan }\end{array}$ \\
\hline
\end{tabular}

Gambar 1 Bagan Tahapan Penelitian

\section{HASIL DAN PEMBAHASAN}

Berdasarkan hasil sebaran angket yang di lakukan kepada 54 responden, respon yang di berikan terhadapat kendala yang dihadapi orangtua dalam mendidik anak pada saat pandemi adalah sebagai berikut:

Tabel 1. Hasil Presentasi data

\begin{tabular}{|c|c|c|c|}
\hline \multirow{3}{*}{$\begin{array}{c}\text { Indikator } \\
\text { Faktor } \\
\text { Internal }\end{array}$} & \multirow{4}{*}{$\begin{array}{c}\begin{array}{c}\text { Sub } \\
\text { indikator }\end{array} \\
\text { Karakteristik } \\
\text { Minat } \\
\text { Kecakapan }\end{array}$} & \multicolumn{2}{|c|}{ Hasil Presentase } \\
\hline & & $26 \%$ mengalami kesulitan & \multirow{2}{*}{$\begin{array}{l}74 \% \text { Tidak mengalami kesulitan } \\
28 \% \text { tidak memiliki kesamaan minat }\end{array}$} \\
\hline & & $\begin{array}{l}72 \% \text { memiliki kesamaan } \\
\text { minat }\end{array}$ & \\
\hline & & $\begin{array}{l}\text { 28\% Memiliki Kecakapan } \\
\text { dalam mendidik AUD }\end{array}$ & $\begin{array}{l}72 \% \text { tidak memiliki kecakapan } \\
\text { dalam mendidik AUD }\end{array}$ \\
\hline & Pengalaman & 83\% memiliki pengaruh & 17\% tidak memiliki pengaruh \\
\hline & Sikap & $\begin{array}{l}62 \% \text { memiliki sikap tegas } \\
\text { dan disiplik }\end{array}$ & $\begin{array}{l}38 \% \text { tidak memiliki sikap tegas dan } \\
\text { disiplin }\end{array}$ \\
\hline & Motivasi & $\begin{array}{l}91 \% \text { selalu memberikan } \\
\text { semangat setiap saat }\end{array}$ & $\begin{array}{l}9 \text { persen tidak selalu memberikan } \\
\text { semangat setiap saat }\end{array}$ \\
\hline & Konsentrasi & $65 \%$ memiliki konsentrasi & $35 \%$ tidak memiliki konsentrasi \\
\hline & Kecerdasaran & $\begin{array}{l}70 \% \text { memiliki kecerdasan } \\
\text { dalam mengajar }\end{array}$ & $\begin{array}{l}30 \% \text { tidak memiliki kecerdasan } \\
\text { dalam mengajar }\end{array}$ \\
\hline & $\begin{array}{l}\text { Kesiapan } \\
\text { mental dan } \\
\quad \text { fisik }\end{array}$ & $\begin{array}{l}94 \% \text { memiliki kesiapan } \\
\text { mental dan fisik dalam } \\
\text { mendidik AUD }\end{array}$ & $\begin{array}{l}\text { 6\% Tidak memiliki kesiapan mental } \\
\text { dan fisik dalam mendidik AUD }\end{array}$ \\
\hline \multirow{7}{*}{$\begin{array}{c}\text { Faktor } \\
\text { Eksternal }\end{array}$} & Pendidik & $78 \%$ pemberian tugas jelas & $22 \%$ pemberian tugas kurang jelas \\
\hline & $\begin{array}{l}\text { Lingkungan } \\
\text { (waktu) }\end{array}$ & $\begin{array}{lr}56 \% & \text { lingkungan } \\
\text { berpengaruh } & \text { terhadap } \\
\text { proses mendidik anak AUD }\end{array}$ & $\begin{array}{l}\text { 44\% Lingkungan tidak perpengaruh } \\
\text { terhadap proses mendidik AUD }\end{array}$ \\
\hline & $\begin{array}{l}\text { Teman } \\
\text { Sebaya }\end{array}$ & $\begin{array}{l}57 \% \text { memiliki teman sebaya } \\
\text { ketika belajar di rumah }\end{array}$ & $\begin{array}{l}43 \% \text { tidak memiliki teman sebaya } \\
\text { ketika belajar di rumah }\end{array}$ \\
\hline & Masyarakat & $25 \%$ berpengaruh & $75 \%$ tidak perpengaruh \\
\hline & Kurikulum & $83 \%$ sesuai & $17 \%$ tidak sesuai \\
\hline & Media & $57 \%$ sudah menunjang & $43 \%$ kurang menunjang \\
\hline & $\begin{array}{l}\text { Sarana dan } \\
\text { Prasana }\end{array}$ & $\begin{array}{l}95 \% \text { menunjang } \\
\text { pembelajaran dan mendidik } \\
\text { AUD }\end{array}$ & 5\% Tidak menunjang \\
\hline
\end{tabular}


Berdasarkan hasil data yang diperoleh bahwa memang ternyata kendala-kendala yang dihadapi orangtua ketika mendidik anak pada masa pandemi adalah di pengaruhi oleh faktorfaktor internal dan eksternal yang disampaikan oleh Helmawati (Helmawati, 2014). Ternyata faktor yang lebih banyak mendominasi adalah faktor internal dalam hal kecakapan. Kecakapan pada faktor ini jelas bahwa orangtua masih banyak yang belum memahami bagaimana mendidik anak dikala pandemi terutama untuk anak usia dini, pada pembelajaran yang dilakukan dirumah akan berhasil jika memang guru dan orangtua sama sama memiliki kecakapan dalam hal mendidik anak terutama pembelajaran yang dilakukan oleh orang tau di rumah saat masa pandemi. Menurut Dewi (2020) menjelaskan bahwa memang pembelajaran di rumah saat masa pandemi dapat berjalan dengan baik ketika kerja sama orangtua dan guru berjalan dengan baik. Tidak hanya itu kecapakan memang menjadi poin penting untuk orangtua ketika mendidikan anak, sehingga ketika orangtua memahami bagaimana anak belajar ketika di rumah dan bagaimana sikap orangtua yang harus dilakukan proses pembelajaran pun agar berjalan dengan cukup baik, karena ketika orangtua paham bagaimana memberikan pemahaman, memberikan kasih saying, memberika pengertian kepada anak dipengaruhi juga oleh sinergitas orangtua dan guru maka proses pembelajaran akan berhasil (Purandina \& Winaya, 2020).

Kendala-kendala yang di dahapi secara internal tidak begitu berpengaruh karena jika dilihat berdasarkan data yang diperoleh bahwa orangtua sudah memahami karakteristik bagaimana orangtua harus mengajar, memahmi minat anak yang berbeda, pengalamanpengalaman yang dapat mempengaruhi orangtua ketika belajar serta terus memotivasi anak untuk dapat terus belajar meskipun saat masa pandemi serta kecerdasan orangtua dalam hal mendidik anak cukup juga kesiapan orangtua dalam menghadapi pembelajaran saat dirumah di respon dengan baik. Sehingga disimpulkan bahwa faktor internal kecakapan orangtua dalam mendidik anak yang perlu untuk digali agar tidak adanya kendala dalam pembelajaran pemahaman, kasih sayang agar anak dapat mengerti dan senang ketika melakukan pembelajaran di rumah. Namun memang pada dasarkan setiap orang memiliki kendala sendiri dalam proses pembelajaran atau saat mendidik anak di rumah, terbukti bahwa berdasarkan data yang diperoleh bahwa orangtua sebanyak $74 \%$ tidak mengalami kendala dalam mendidik anak usia dini pada saat pandemi, sedangkan $26 \%$ dari orangtua mengalami kesulitan dalam mendidik anak pada saat pandemi. Hal ini perlu sangat di perhatikan karena peran orangtua saat pandemi sangat diperlukan apalagi saat masa pandemi. Maka jika dilihat dari kendala internal dalam mendidik anak, orangtua perlu diberikan edukasi (Cahyati \& Kusumah, 2020) agar tau bagaimana cara memberikan pemahaman serta paham akan konsep tujuan sekolah PAUD atau tujuan dari setiap pembelajaran yang dilakukan. Karena tidak setiap orangtua berpendidikan tinggi, maka perlu perhatian khusus baik dari lembaga sekolah maupun dari pribadi yang ingin terus belajar dalam meningkatkan kualitas pendidikan pada anak, utamanya pada anak usia dini.

Kendala orangtua juga terlihat dari faktor eksternalnya yaitu pendidik, lingkungan (waktu dan tempat), teman sebaya, masyarakat, kurikulum, media serta sarana dan prasana. Berdasarkan data yang diperoleh bahwa faktor yang lebih dominal pada faktor eksternal adalah media. Pada pada proses pembelajaran berlangsung Media merupakan alat untuk menyalurkan infomasi pada saat proses pembelajaran (Muhson, 2010), sehingga media pembelajaran baik disekolah maupun dirumah menjadi hal yang sangat penting apalagi untuk anak usia dini yang masih usia konkrit. Media pembelajaran pada anak usia dini menjadi sarana atau alat untuk stimulasi perkembangan anak (Khasanah et al., 2011). Maka dengan ini pendidik yang bekerja sama dengan orangtua ketika akan melakukan atau memberikan suatu pembelajaran terutama berbasis daring maka di perlukan melihat terlebih dahulu saran dan prasana yang ada disekitaran orangtua murid, karena ini dapat menjadi kendala saat proses pembelajaran berlangsung. Maka sebab itu sebaiknya media yang digunakan untuk proses pembelajaran agar memudahkan orangtua maka gunakan alat alat yang ada sekitar anak dan orangtua dirumah. 
Kendala-kendala yang dihadapi saat pandemi ini merupakan awal mula bagaimana orangtua siap atau tidaknya menyikapi pendidikan pada abad 21 yang cenderung sesuai dengan pekembangan teknologi yang begitu pesat. Dengan ini juga orangtua ketika dirumah saat ini banyak sekali tantangan yang harus dikuasi oleh orang tau tersebut dimana system pembelajaran di rumah ini akan secara fleksibel di galakan, dimana kolaborasi antara pendidik, orangtua, anak usia dini dan lembaga menjadi kunci sukses nya dalam mendidik, begitu pun dengan orangtua yang harus mampu siap dalam menjawab tantangan di era globalisasi baik dari segi pendidikan maupun skill yang harus dimiliki oleh anak ketika dia beranjak dewasa sehingga dia mampu dalam mengaplikasikan ilmunya di dunia kerja serta harus responsive dalam perubahan. Maka sangat penting sekali di perlukan kedua indicator internal dan eksternal dalam mendidik anak yang harus dimiliki oleh orangtua terutama kesiapan mental dan fisik serta pengetahuan pemahaman mengenai bagaimana mendidik anak ketika di rumah atau masa pandemi.

Keterbatasan pada penelitian ini adalah terkait kecakapan orangtua dalam mendidik anak, yang sebenarnya kecakapan ini menjadi hal atau faktor yang paling penting, kerena ketika orangtua tidak cakap dalam mendidik anaknya maka apa yang menjadi tujuan dari pembelajaran yang dilakukan tidak secara menyeluruh tersampaikan, berbeda dengan orangtua yang sudah cakap, skillnya mumpuni dan pengetahuan mengenai pengasuhannya paham maka pembelajaran akan mudah diberikan baik dari segi bagaimana cara memberikan pemahaman kepada anak, bagaimana cara menumbuhkan karakter dalam diri anak serta skill yang harus dimiliki oleh anak. Kerana pendidikan Indonesia abad ke-21ini sangat dihadapkan dengan sejumlah tantangan dan peluang (Majir, 2019) sehingga kecakapan orangtua dalam mendidik harus cukup memadai dan juga Pola pengasuhan dari guru, orang dewasa, orangtua, dan lingkungan sangat berperan dalam menstimulasi seluruh potensi kecerdasan anak sehingga dapat menentukan bagaimana karakter, kepribadian, dan sikap anak ketika sudah dewasa (Fitriani, 2015).

\section{SIMPULAN}

Kendala orangtua dalam mendidik anaknya pada masa panedemi dipengaruhi dua faktor yaitu internal berupa kecakapan orangtua dan eksternal berupa lingkungan baik sekolah maupun masyarakat. Kecakapan orangtua dalam hal memberikan pemahaman, kasih sayang, pengerjaan tugas dan perkembangan anak agar pembelajaran yang dilakukan dirumah di saat pandemi dapat efektif. Serta perlunya perhatian guru agar memberikan tugas melalui kerjasama dengan orangtua Karena keterpaduan antara orangtua, guru dan siswa adalam kunci utama proses pembelajaran.

\section{UCAPAN TERIMA KASIH}

Peneliti mengucapakan terima kasih kepada teman-teman yang telah membantu untuk menyebarkan link form angket serta orangtua siswa yang menjadi sampel dalam penelitian.

\section{DAFTAR PUSTAKA}

Andriani, T. (2012). Permainan tradisional dalam membentuk karakter anak usia dini. Sosial Budaya, 9(1), 121-136. https:// doi.org/http:/ /dx.doi.org/10.24014/sb.v9i1.376

Arifin, A.-R. K., \& Fardana, N. A. (2014). Peran Pendidik PAUD dalam Mengimplementasikan Pendidikan Karakter Melalui Metode Pembelajaran Sentra dan Lingkaran. Jurnal Psikologi Pendidikan Dan Perkembangan, 3(3), 188-198. http:/ /journal.unair.ac.id/filerPDF/jpppaa5c340a9efull.pdf

Cahyati, N., \& Kusumah, R. (2020). Peran Orangtua Dalam Menerapkan Pembelajaran Di Rumah Saat Pandemi Covid 19. Jurnal Golden Age, Universitas Hamzanwadi, 04(1), 152159. 
DOI: 10.31004/obsesi.v5i2.746

Darmalaksana, W., Hambali, R. Y. A., Masrur, A., \& Muhlas. (2020). Analisis Pembelajaran Online Masa WFH Pandemic Covid-19 sebagai Tantangan Pemimpin Digital Abad 21. Karya Tulis Ilmiah (KTI) Masa Work From Home (WFH) Covid-19 UIN Sunan Gunung Djati Bandung Tahun 2020, 1(1), 1-12.

Dewi, W. A. F. (2020). Dampak COVID-19 terhadap Implementasi Pembelajaran Daring di Sekolah Dasar. EDUKATIF: JURNAL ILMU PENDIDIKAN, 2(1), 55-61. https://doi.org/10.31004/edukatif.v2i1.89

Fitriani, L. (2015). Peran pola asuh orangtua dalam mengembangkan kecerdasan emosi anak. Lentera, 17(1). https:/ / doi.org/DOI: https://doi.org/10.21093/lj.v17i1.431

Helmawati, P. K. (2014). Teori dan Praktis. Bandung: Remaja Rosda Karya, 230-234.

Khasanah, I., Prasetyo, A., \& Rakhmawati, E. (2011). Permainan tradisional sebagai media stimulasi aspek perkembangan anak usia dini. PAUDIA: Jurnal Penelitian Dalam Bidang Pendidikan Anak Usia Dini, https://doi.org/https://doi.org/10.26877/paudia.v1i1.261

Majir, A. (2019). Blended Learning dalam Pengembangan Pembelajaran Suatu Tuntutan Guna Memperoleh Keterampilan Abad ke-21. Buana Pendidikan: Jurnal Fakultas Keguruan Dan Ilmu Pendidikan, 15(28), 103-117. https:// doi.org/10.46984/sebatik.v23i2.783.

Muhson, A. (2010). Pengembangan Media Pembelajaran Berbasis Teknologi Informasi. Jurnal Pendidikan Akuntansi Indonesia, 8(2). https://doi.org/10.21831/jpai.v8i2.949

Purandina, I. P. Y., \& Winaya, I. M. A. (2020). Pendidikan Karakter di Lingkungan Keluarga Selama Pembelajaran Jarak Jauh pada Masa Pandemi COVID-19. Cetta: Jurnal Ilmu Pendidikan, 3(2), 270-290. https://doi.org/https://doi.org/10.37329/cetta.v3i2.454

Putra, A. T. A. (2020). Transformasi Nilai Pendidikan Islam Anak di PAUD Sultan Qaimuddin Kendari Pada Masa Pandemic Covid 19. Murhum, 79-90. https://doi.org/https://doi.org/10.37985/murhum.v1i1.8

Salkiah, B. (2020). Perubahan Paradigma Pendidikan dan Ekonomi di Masa Pandemi Covid19. Media Bina Ilmiah, 3781-3787. https://doi.org/https://doi.org/10.33758/mbi.v15i1.647

Sari, D. A., Mutmainah, R. N., Yulianingsih, I., Tarihoran, T. A., \& Bahfen, M. (2020). Kesiapan Ibu Bermain Bersama Anak Selama Pandemi Covid-19,"Dirumah Saja." Jurnal Obsesi: Jurnal Pendidikan Anak Usia Dini, 5(1), 475-489. https://doi.org/https://doi.org/10.31004/obsesi.v5i1.584

Suryani, L. (2007). Analisis permasalahan pendidikan anak usia dini dalam masyarakat indonesia. Jurnal Ilmiah Visi, 2(1), 42-48. https://doi.org/https://doi.org/10.21009/JIV.0201.6

Syafrida, S., \& Hartati, R. (2020). Bersama Melawan Virus Covid 19 di Indonesia. SALAM: Jurnal Sosial Dan Budaya Syar-I, 7(6), 495-508. https://doi.org/10.15408/sjsbs.v7i6.15325.

Yunus, N. R., \& Rezki, A. (2020). Kebijakan Pemberlakuan Lock Down Sebagai Antisipasi Penyebaran Corona Virus Covid-19. Salam: Jurnal Sosial Dan Budaya Syar-I, 7(3), 227238. https:// doi.org/DOI: 10.15408/sjsbs.v7i3.15083 